\title{
Problems of Oil Refining Industry Development in Russia
}

\author{
Zakaev Dokka ${ }^{1}$, Nikolaichuk Liubov ${ }^{2}$ and Filatova Irina ${ }^{3}$ \\ ${ }^{1,2,3}$ Department of Economics, Accounting and Finance, Saint Petersburg Mining University, Russian Federation
}

ORCIDs : 0000-0001-5013-1787 (Nikolaichuk Liubov ), 0000-0002-0505-8274 (Filatova Irina)

\begin{abstract}
This article is review one and discusses the development trend of Russian oil industry, in particular, the oil refining sector. Nowadays, the Russian oil refining complex is characterized by insufficient volumes of secondary oil refining by selling low value-added products to the domestic and foreign markets, lagging behind in technical and technological development. The existing modernization process is lengthy and requiressignificant investments. This article also discusses ways out of the current situation of underinvestment of processing facilities. So, as measures that increase the investment attractiveness of refineries, one can distinguish such as: increasing the stability of tax legislation, eliminating price distortions, improving the quality of products, expanding export opportunities. However, the key decision may be the use of the public-private partnership method - the conclusion of quadripartite agreements with the authorities.
\end{abstract}

Keywords: Investments, Nelson Index, oil refineries, output of light oil production, quadripartite agreements, Russian oil sector

\section{INTRODUCTION}

Russia is one of the world leaders in terms of oil reserves (Fig 1). Interms of oil production, Russia took the 3rd place in the world in 2018.

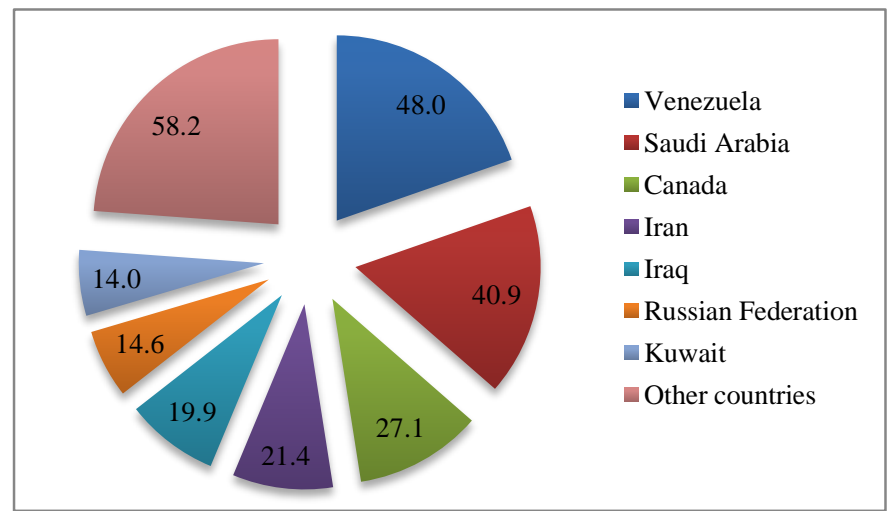

Figure 1. Proven oil reserves in the world in 2018, billion tons Source: built by authors according to [1, p. 14]

About half of the oil produced in Russia is exported, the rest is refined. In terms of oil refining, Russia ranks third in the world after the USA and China [1, p. 27]. In 2018, 51.5\% of the total oil production was processed, 40 million tons of gasoline, almost 80 million tons of diesel fuel and 48 million tons of fuel oilwas produced at Russian oil refineries [2]. The export of petroleum products amounted to 150 million tons in 2018 [3].

The Russian oil refining industry is considering to be developing industry. There is an annual increase in the share of oil refining in production volumes. In 2018, the volumes of Russian oil refining increased, the share of refining in production volumes on average for companies exceeded $65 \%$. Despite the positive dynamics, it is necessary to increase the volume and depth of oil refining, which in turn requires the creation and implementation of a mechanism for the transition from the raw materials sector to the refining sector.

Most refineries are part of vertically integrated oil companies. The refining depth ranges from $64 \%$ to $99 \%$ at various refineries, while the output of light oil production varies from $55 \%$ to $84 \%$.

It is very important to understand all reasons which leads to such situation in oil refining sector in Russia.

\section{II.DISCUSSION}

Nowadays the main problem of most Russian oil refineries is the low depth of oil refining. The average oil refining depth in Europe is $85 \%$, in the USA - 96\% [4]. In 2018, the oil refining depth in Russia averaged about $81 \%$ (Fig. 2).

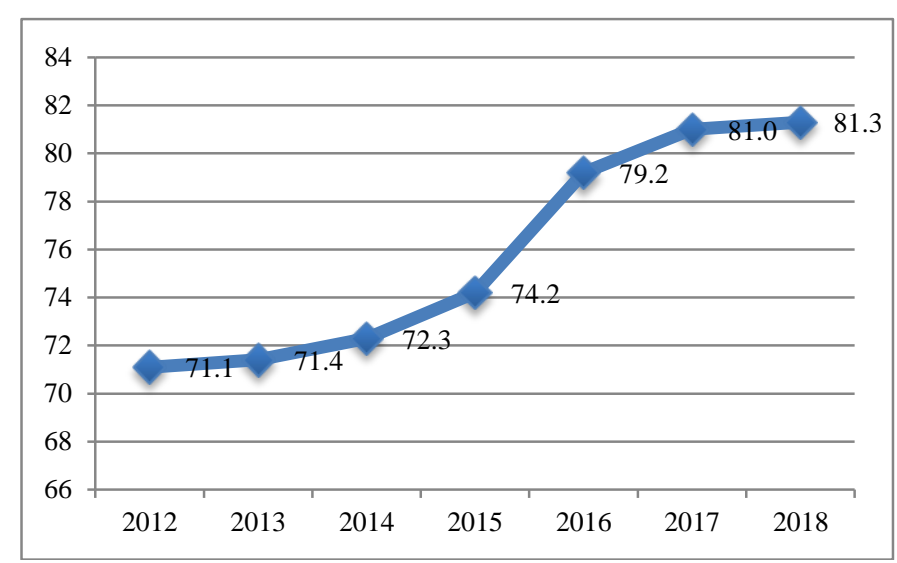

Figure 2. The oil refining depth in Russia, \% Source: built by authors according to [5], [6] 
The Nelson Index is one of the indicators evaluating the economic efficiency of refineries, shows how many times the equipment installed at a refinery is more complicated than the installation for primary distillation of crude oil, which characterizes the technological perfection of fixed assets.

According to the analysis, in 2017 the oil refining depth at Russian refineries averaged $81 \%$. According to the same forecast, the average value of the Nelson index on average at Russian refineries is 6 , while at modern foreign refineries this indicator reaches 14 [7]. Nevertheless, today a number of Russian refineries have reached high values of the index 9-10.

The main factor leading to the increase in the pace of modernization in the oil refining industry was the introduction in 2008 of European environmental standards. Today, established high environmental standards for finished products lead to difficulties for domestic oil products to compete with foreign goods. Oil refining involves several stages. An increase in the depth of oil refining occurs due to the introduction of deep destruction processes and ennoblement processes.

In order to sell petroleum products both on the domestic and foreign markets, the products must comply with the established technical requirements and have the best cost characteristics. One of the significant problems in the development of the Russian oil refining industry is that a number of projects are based on foreign technologies. There is a significant gap in the scientific and technical base of Russian and foreign research companies.

According to the Russian Energy Strategy Russia until 2030, a refining depth of $90 \%$ on average at Russian oil refineries with an output of light oil products of $73 \%$ is proposed [8]. The general scheme for the development of the oil industry also provides increasing in the share of the output of light oil products $(75 \%$ by 2035$)$ and increasing in the depth of oil refining to $91 \%$ by 2035 [9]. Thus, the development trend of oil refineries as part of vertically integrated companies lies in their modernization: increasing the depth of refining, increasing the share of the output of light oil products, updating basic production assets in general, changing the production basket, providing the domestic market and exporting with final high-quality products.

Nowadays, Russian oil refining industry is characterized by insufficient volumes of oil refining, sales of low value-added products to the domestic and foreign markets, and lagging behind in technical and technological development. The existing modernization process is lengthy and requires significant investments.

At the beginning of the $21^{\text {st }}$ century, a massive modernization of Russian refineries began, which was caused by the development of oil product markets and high incomes of oil companies. There was a decrease in investment in the development of oil refining with a subsequent drop in oil prices. Nowadays, the share of crude oil exports is still at 4547\% (Fig. 3).

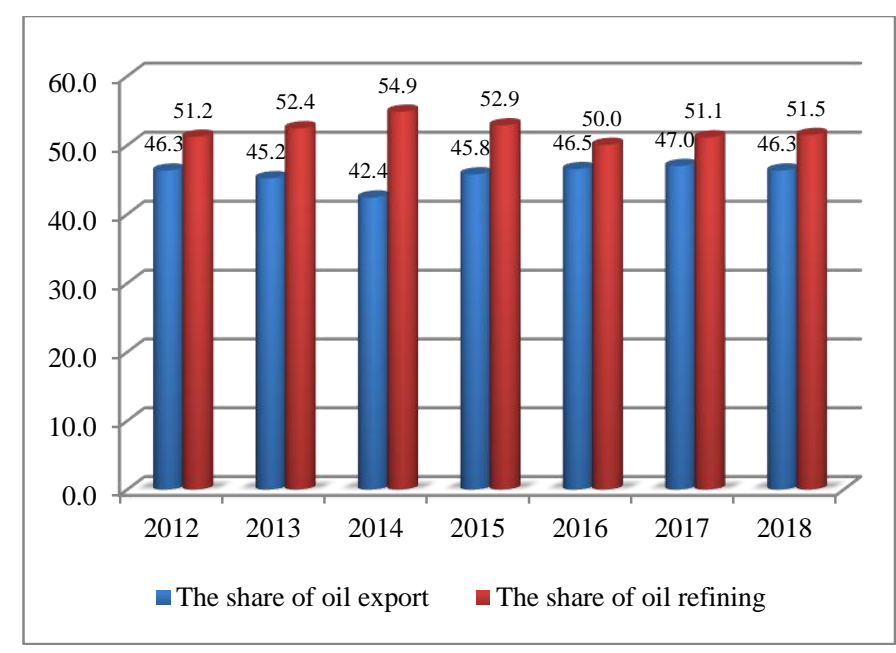

Figure 3. The share of oil export and refining in total production, $\%$

Source: built by authors according to [5], [10]

In 2011, Russia began the planned modernization of oil refineries, which generally led to an increase in the volume of oil refining. In order to consistently modernization Russian refineries in 2011, quadripartite agreements (four-power agreements) were concluded between oil companies and government authorities regulated the volume and timing of modernization. This led to the construction of new refineries planned by the companies and the modernization of existing ones, and, consequently, to an increase in the depth of oil refining despite the drop in oil prices.

The implementation of the four-power agreements obliging companies to upgrade their refineries leads to significant investments by companies in oil refining, which will make possible to abandon subsidies in the near future without harming companies, the domestic market and the state.

In accordance to the quadripartite agreements, from 2011 to 2017, most of the secondary processing plants were modernized, production of light oil products increased, while fuel oil production decreased. It is expected to achieve a level of refining depth of $91 \%$ with an output of light oil products 79\%. [6, pp.44-46]

Moreover, the tax manoeuvre of 2014 contributed to the growth of crude oil exports in the last five years, which lowered the marginal rates of the export duty on oil and increased the base tax rates for mineral extraction tax (MET). An increase in MET rates leads to the fact that oil refineries buy more expensive raw materials, and this negatively affects the level of profitability of their production. An analysis of Reuters data showed that in 2015, the sale of crude oil on the world market was more profitable than the sale of primary refined petroleum products by $\$ 6$ per ton [11].

At the same time, in part of the tax legislation in 2011, in order to reduce excess profitability in the production and sale of fuel oil, changes were made to the system of customs duties. A system was adopted according to which a gradual reduction in rates for automobile fuel, that is, for products of secondary oil refining, is proposed, which is a kind of subsidy for the refinery. [12] Only in 2016 was an average industry 
margin of Russian refineries - $\$ 4.8$ per barrel due to lower rates for final refined products. [13]

All these changes in the legislation led to the fact that since 2014 there has been a decrease in the volume of primary oil refining and an increase in the volume of secondary refining, which generally leads to an optimization of the structure of oil refining, and the share of light oil products increases in Russia.

\section{CONCLUSIONS}

The priority for the oil refining industry is to provide consumers of the domestic market with high-quality oil products without deficiency. In recent years, the share of oil products exports has remained at the level of $55-60 \%$ of the total refining volume, while this indicator has been declining over the past three years (Fig. 4).

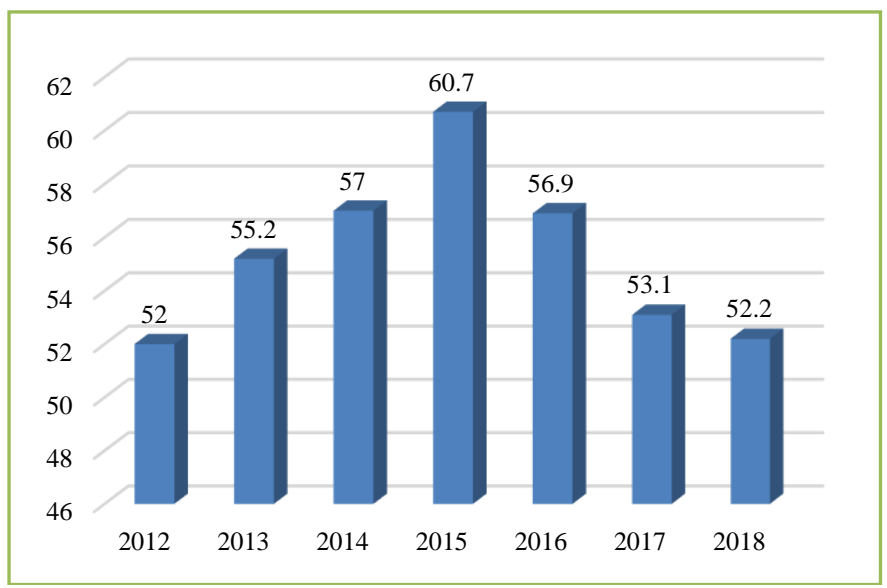

Figure 4. The exports share of petroleum products 2012-2018 Source: built by authors according to [5], [10]

Another development way in oil refining industry is a decreasing in the share of catalyst imports in oil refining. There is a positive trend in terms of import substitution. A number of Russian companies have completely switched to the use of domestic catalysts.

The formation of transportation costs is one of the factors influencing the pricing of Russian petroleum products. In Russia, most refineries are remote from the centers of consumption of petroleum products, which leads to high costs for the products transportation and affects its final cost. According to VYGON Consulting, the difference between the cost of transporting oil and oil products for export is 5-7 dollars per barrel [14]. In order to reduce logistics costs and increase the competitiveness of Russian petroleum products, it is necessary to revise the tariffs for the transportation of these within the country by various modes of transport. It is possible to compensate high logistics costs by reducing operating costs partially.

Reducing operating costs is possible by increasing the depth of oil refining and a more complete use of raw materials.
When refineries are modernized, improved technological schemes and more productive equipment lead to lower costs, which in turn leads not only to a reduction in the loss of working time and raw materials, but also to a reduction in energy consumption.

In order to develop the oil refining industry, oil companies need to invest in innovations, modernize existing production regardless of government support, increase the level of the depth of raw materials processing, and diversify production depending on demand and territorial location.

The investment attractiveness of the refinery has a direct impact on the intensive development of the enterprise, increasing production efficiency, as well as competitiveness.

Nowadays, Russian companies lose not only in added value, including in the export of hydrocarbons and their processed products, but losses also occur due to the import of highquality finished products.

Investment attractiveness remains low due to the distrust of companies in the state regarding tax legislation. [15]

The price of oil has exceeded the mark of $\$ 70$ per barrel for the first time since falling at the end of 2014 since April 2018. This is an opportunity to increase investment in the modernization of production (Fig. 5).

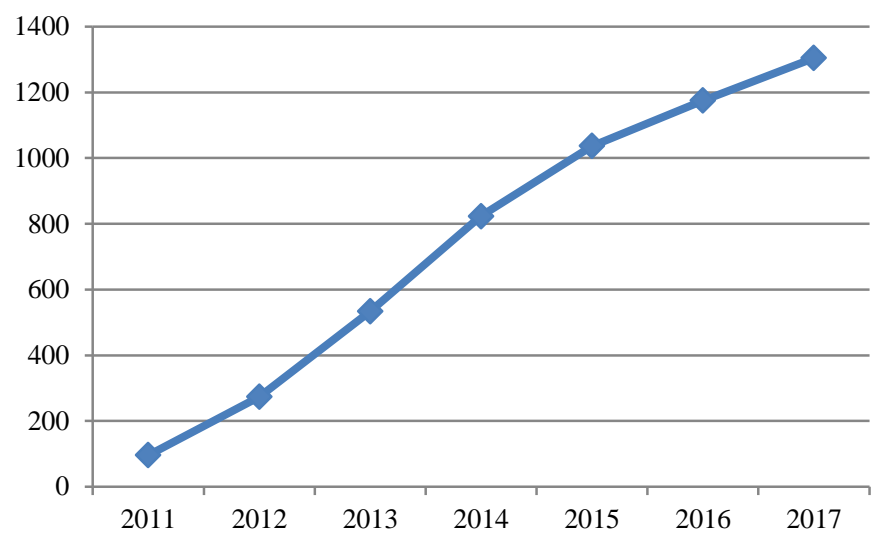

Figure 5. Investments in the modernization of oil refineries in accordance with the plans of oil companies, billion rubles

Source: built by authors according to statistics from Energy Ministry of the Russian Federation

40 billion rubles were invested in Russian oil refining in 2006; in 2010, the amount exceeded 1,000 billion rubles.

Companies need to accelerate the modernization and expansion of oil refineries in the face of an insignificant but stable rise in oil prices. Expanding production and increasing the depth of processing of raw materials will reduce dependence on equipment exports, ensure domestic demand with high-quality products and increase the competitiveness of Russian companies in the international market.

There are a number of measures to increase the investment attractiveness of oil refineries, such as: increasing the stability 
of tax legislation, eliminating price distortions, improving the quality of products, expanding export opportunities, etc.

The stability of the legislation will minimize a number of risks and uncertainties, which will increase the investment attractiveness of the industry. Without an increase in funding, it is not possible to increase the processing depth to the planned values. The solution in this situation may be the use of public-private partnership.

\section{REFERENCES}

[1] BP Statistical Review of World Energy (June 2019). BP Statistical Review of World Energy 2019.68 ${ }^{\text {th }}$ edition.Available from: https://www.bp.com/content /dam/bp/business-sites/en/global/corporate/pdfs/energyeconomics/statistical-review/bp-stats-review-2019-fullreport.pdf.

[2] Analytical Center for the government of the Russian Federation. Energy Bulletin(January 2019). Gas demand in Eastern Europe. Available from: https://ac.gov.ru/files/publication/a/20397.pdf.

[3] Federal Customs Service. (2018).Russia's export of the most important goods for 2017, 2018. Available from: http://customs.ru/.

[4] Neftegaz.RU. (2016) Oil refining depth in Russia, Europe and the USA. Available from:https://neftegaz.ru/analisis/view/8485-Glubinapererabotki-nefti-v-Rossii-Evrope-i-SShA.

[5] Ministry of Energy of the Russian Federation. (2017) Refining of oil and gas condensate.Available from://http://minenergo.gov.ru/node/1212.

[6] Molodtsov, K. (2018) Oil refining: in response to challenges. Oil and gas vertical, No. 3/2018.44-46. Available from: http://www.cdu.ru/tek_russia /articles/2/556/.

[7] Ministry of Energy of the Russian Federation. (2015) Russian Energy Strategy for the Period until 2035. Available from: http://www.energystrategy.ru /ab_ins/source/ES-2035_09_2015.pdf.

[8] Ministry of Energy of the Russian Federation. (2013) Russian Energy Strategy for the Period until 2030. Available from: https://minenergo.gov.ru/node/1026/.

[9] The analytical service of the Oil and Gas Vertical. (2017). The general scheme for the development of the oil industry in Russia until 2015 or Gensham and the elements of life. No. 3-4, 2017. pp. 10-11. Available from: http://www.ngv.ru/upload/iblock/4f8/4f84c5cfd d33ae66ccd08b479c92f6cd.pdf.

[10] Analytical Center for the government of the Russian Federation. Energy Bulletin (January 2018). Oil industry: 2017 results and short-term prospects.Available from: http://ac.gov.ru/publications /bulletin/.

[11] Reuters News Agency. Newswire Services https://www.reutersagency.com/en/products/newswires/.

[12] The Law of the Russian Federation of May 21, $1993 \mathrm{~N}$ 5003-I "Customs Tariff". Available from: http://base.garant.ru/10101366/.

[13] VYGON Consulting. (July 2017). Russian oil industry: 2016 results and prospects for 2017-2018 Part 2: refining and marketing. Available from: https://vygon.consulting/products/issue-973/.

[14] VYGON Consulting. (May 2015). Oil tax maneuvers. what's next?Available from: https://vygon.consulting/ upload/iblock/2af/vygon_consulting_taxmaneuvers.pdf.

[15] Litvinenko V.S., Sergeev I.B. (2019) Innovations as a Factor in the Development of the Natural Resources Sector. Studies on Russian Economic Development, No. 30/2019.637-645. Available from: https://rdcu.be/b1wuU. 